\title{
Mirosław Czekaj
}

Skarbnik Miasta Warszawy

e-mail:mczekaj@um.warszawa.pl

\section{KIERUNKI EWOLUCJI PLANOWANIA BUDŻETOWEGO W JEDNOSTKACH SAMORZĄDU TERYTORIALNEGO. POWIĄZANIA PLANOWANIA STRATEGICZNEGO Z WIELOLETNIM PLANOWANIEM FINANSOWYM \\ DIRECTIONS OF THE EVOLUTION OF BUDGET PLANNING IN LOCAL GOVERNMENT UNITS. RELATIONSHIPS BETWEEN STRATEGIC PLANNING AND LONG-TERM FINANCIAL PLANNING}

DOI: 10.15611/pn.2018.521.04

JEL Classification: H720

Streszczenie: Poddano badaniu sposób zarządzania jednostkami samorządu terytorialnego w zakresie dotyczącym kierunków zmian procesu planowania budżetowego w kontekście odnoszącym się do horyzontu planistycznego. Badanie dotyczyło największej jednostki samorządowej w Polsce, tj. m.st. Warszawy. Wyniki badania regulacji wewnętrznych oraz wdrożonych rozwiązań z lat 2008-2017 wskazują, iż lokalna polityka finansowa zmienia się, modyfikując proces i dokumenty planistyczne, pierwotnie dotyczące tylko budżetu rocznego, w kierunku budżetów wieloletnich w postaci wieloletniej prognozy finansowej (WPF) w układzie klasyfikacji budżetowej, jak i w układzie zadaniowym. Dopełnieniem procesu podnoszenia sprawności i efektywności w planowaniu i wydatkowaniu środków publicznych może stać się zaproponowany mechanizm powiązania celów i zadań określonych w strategii JST z kierunkami wydatków określonych w WPF i rocznym budżecie.

Słowa kluczowe: planowanie budżetowe, planowanie wieloletnie, planowanie strategiczne.

Summary: The way of managing and changing territorial self-government units in the field of the budget planning process, especially the planning horizon, was examined. The study is about the largest self-government unit in Poland, i.e. the capital city of Warsaw. The results of a review of the internal regulation and implemented solutions from 2008-2017 indicate that the local financial policy evolves. It is modifying the planning process and documents, which originally applied only to the annual budget, towards multiannual budgets in the form of long-term financial forecast (WPF) in both; the budgetary classification and activity based configurations. The process of increasing efficiency and effectiveness in the planning and spending of public funds may be complemented by the proposed mechanism which links 
the objectives and tasks specified in the local government strategy with the directions of expenditure specified in the WPF and the annual budget.

Keywords: budget planning, multi-annual planning, strategic planning.

\section{Wstęp}

Realizacja zadań jednostek samorządu terytorialnego (JST) wymaga zapewnienia ich odpowiedniego finansowania, z reguły w perspektywie wieloletniej. Do skutecznego i sprawnego zarządzania JST niezbędne stają się analizy i dokumenty umożliwiające dokonanie oceny długoterminowego potencjału finansowego JST w zakresie wymaganych wydatków bieżących oraz możliwych do poniesienia wydatków inwestycyjnych w kontekście dopuszczalnego i uzasadnionego poziomu środków zwrotnych. Analizy powinny uwzględniać również potencjalny negatywny wpływ czynników zewnętrznych na sytuację finansową JST oraz sposoby zabezpieczenia się przed ich negatywnymi skutkami. Celowe jest zatem opracowanie i dysponowanie przez JST dokumentem, w którym ryzyka te opisano i zwymiarowano, a następnie poddano systemowo monitorowaniu. Funkcje te może z powodzeniem pełnić wieloletnia prognoza finansowa (WPF), od $2011 \mathrm{r}$. obligatoryjne narzędzie planowania finansowego $\mathrm{w}$ JST. Celem pracy jest zbadanie procesu zmian w podejściu do planowania budżetowego na przykładzie największej jednostki samorządu terytorialnego w Polsce, ze szczególnym uwzględnieniem zmian dotyczących horyzontu planistycznego i związanych z tym dokumentów. Ponadto, na podstawie analizy procesu planowania wieloletniego, przedstawiono w zakończeniu artykułu propozycje podniesienia efektywności procesu planistycznego poprzez zastosowanie mechanizmu powiązania między strategią jednostki samorządu terytorialnego a jej WPF.

\section{Kierunki ewolucji planowania finansowego}

JST realizują przypisany im zakres zadań w warunkach kompromisu między potrzebami mieszkańców a możliwościami budżetowymi. Lokalna polityka finansowa powinna uwzględniać uwarunkowania wewnętrzne i zewnętrzne oraz identyfikować ryzyka ekonomiczne, w tym odnoszące się do pełnego zabezpieczenia terminowej obsługi zobowiązań i utrzymania płynności finansowej [Krajewska, Jońca 2012]. Kluczowe wybory dotyczące poziomu nakładów na inwestycje, poziomu zadłużenia oraz stopnia spełnienia norm regulacyjnych dotyczących długu i nadwyżki dochodów bieżących nad wydatkami bieżącymi przez JST egzemplifikują się w WPF. Specyficzne cechy JST dotyczące ich wielkości i złożoności zadań oraz charakter i tempo rozwoju zaawansowanych metod zarządzania gospodarką finansową daną JST przekładają się na specyficzny, indywidualny charakter metod 
i dokumentów planistycznych. Planowanie budżetowe zmienia się w sposób powolny, w głównej mierze wymuszony przez zmiany regulacji prawnych [Dylewski 2014]. Jednakże w zakresie systemu finansowego JST ustawodawca nie zdecydował się na przykład na wprowadzenie obowiązku sporządzania budżetu JST w układzie zadaniowym, w odróżnieniu od zastosowania takich regulacji dla budżetu państwa [Miemiec 2015]. Ewolucję w procesie planowania finansowego JST zbadano na przykładzie m.st. Warszawy - największej i najbardziej złożonej organizacyjnie JST, która w WPF wykazuje ponad 3,3 tys. wieloletnich przedsięwzięć (w tym blisko 1,0 tys. przedsięwzięć majątkowych) realizowanych przez ponad 1,1 tys. tzw. dysponentów środków budżetowych [https1]. Wydatki budżetowe Warszawy są najwyższe spośród JST w Polsce i sięgają 17,7 mld zł [https2]. Wyniki badania treści i formy dokumentów planistycznych oraz sprawozdawczych w zakresie identyfikacji zmian i innowacji dotyczących procesu planowania budżetowego m.st. Warszawy zaprezentowano w tab. 1.

Tabela 1. Etapy ewolucji planowania budżetowego na przykładzie m.st. Warszawy

\begin{tabular}{|c|c|c|}
\hline Rok & Wdrożenie & Opis \\
\hline 1 & 2 & 3 \\
\hline \multirow{3}{*}{2008} & $\begin{array}{l}\text { Budżet zadaniowy w pełni po- } \\
\text { wiązany z budżetem według } \\
\text { klasyfikacji budżetowej }\end{array}$ & $\begin{array}{l}\text { Opracowano i wdrożono budżet w układzie zadaniowym } \\
\text { obejmujący } 11 \text { sfer, } 35 \text { programów, } 204 \text { zadania i } 229 \text { podza- } \\
\text { dań, powiązany systemowo z budżetem w układzie klasyfi- } \\
\text { kacji budżetowej. }\end{array}$ \\
\hline & Polityki długu & $\begin{array}{l}\text { Opracowano odrębny, sformalizowany dokument opisujący } \\
\text { kierunki działań związane z obecnym i planowanym zadłu- } \\
\text { żeniem, w tym dotyczących sposobów ograniczeń ryzyk } \\
\text { związanych z zadłużeniem, np. ryzyka stopy procentowej. }\end{array}$ \\
\hline & $\begin{array}{l}\text { Rozszerzona do } 3 \text { lat perspek- } \\
\text { tywa budżetowa }\end{array}$ & $\begin{array}{l}\text { Wydłużenie z roku do trzech lat prognozowanych dochodów } \\
\text { oraz planowanych wydatków. }\end{array}$ \\
\hline 2009 & $\begin{array}{l}\text { Rozszerzona do } 5 \text { lat perspek- } \\
\text { tywa planistyczna dla progra- } \\
\text { mu inwestycyjnego }\end{array}$ & $\begin{array}{l}\text { Opracowano i wdrożono budżetowy 5-letni plan inwestycyj- } \\
\text { ny będący podstawą do zaciągania zobowiązań wieloletnich. }\end{array}$ \\
\hline \multirow[b]{2}{*}{2010} & $\begin{array}{l}\text { Rozszerzenie budżetu i spra- } \\
\text { wozdań budżetowych o cele i } \\
\text { mierniki realizacji celów }\end{array}$ & $\begin{array}{l}\text { Rozbudowanie budżetu o cele i mierniki realizacji celów } \\
\text { bieżących poprzez wprowadzenie blisko } 1,0 \text { tys. mierników. }\end{array}$ \\
\hline & $\begin{array}{l}\text { Model Wieloletniej Prognozy } \\
\text { Finansowej implementowany } \\
\text { w systemie informatycznym } \\
\text { wspomagającym planowanie } \\
\text { budżetowe }\end{array}$ & $\begin{array}{l}\text { Opracowanie koncepcji i modelu budżetu wieloletniego, } \\
\text { w tym przedsięwzięć bieżących i majątkowych, grupowań } \\
\text { wydatków i dochodów, kontroli dostępności środków, kon- } \\
\text { troli spójności, oraz opracowanie zasad tworzenia raportów. }\end{array}$ \\
\hline 2011 & $\begin{array}{l}\text { Średnio- i długoterminowa per- } \\
\text { spektywa planistyczna w opar- } \\
\text { ciu o WPF w pełni powiązaną z } \\
\text { rocznym budżetem i wykazem } \\
\text { przedsięwzięć wieloletnich sta- } \\
\text { nowiących podstawę do zacią- } \\
\text { gania zobowiązań wieloletnich }\end{array}$ & $\begin{array}{l}\text { Wydłużenie perspektywy planowania do } 2033 \text { r., to jest do } \\
\text { okresu spłaty ostatniego planowanego bądź istniejącego zo- } \\
\text { bowiązania. }\end{array}$ \\
\hline
\end{tabular}


Tabela 1, cd.

\begin{tabular}{|c|l|l|}
\hline 1 & \multicolumn{1}{|c|}{2} & \multicolumn{1}{|c|}{3} \\
\hline 2012 & Perspektywy WPF do 2042 r. & $\begin{array}{l}\text { Wydłużenie perspektywy planowania do 2042 r. oraz mody- } \\
\text { fikacja raportów budżetów wieloletnich, raportów dotyczą- } \\
\text { cych przedsięwzięć. }\end{array}$ \\
\hline 2013 & $\begin{array}{l}\text { Obligatoryjne dostosowanie } \\
\text { WPF do wzoru określonego } \\
\text { przez Ministra Finansów }\end{array}$ & $\begin{array}{l}\text { Modyfikacja raportów, wprowadzenie nowych obszarów } \\
\text { funkcjonalnych, grupowań wydatków i dochodów, interfej- } \\
\text { sów oraz opracowanie i wdrożenie wzorów nowych rapor- } \\
\text { tów. }\end{array}$ \\
\hline 2015 & $\begin{array}{l}\text { Planowanie i sprawozdaw- } \\
\text { czość w dotychczasowym ukła- } \\
\text { i ukie klasyfikacji budżetowej } \\
\text { nowym układzie odnoszącym } \\
\text { się do budżetu obywatelskiego } \\
\text { partycypacyjnego) }\end{array}$ & $\begin{array}{l}\text { Wprowadzenie nowych obszarów funkcjonalnych, opra- } \\
\text { cowanie nowych raportów dla rozwinięcia planistycznego } \\
\text { i sprawozdawczego w układzie odpowiadajacym kształtowi } \\
\text { tzw. budżetu obywatelskiego (partycypacyjnego). }\end{array}$ \\
\hline 2016 & $\begin{array}{l}\text { Perspektywa WPF na okres do } \\
\text { 2045 r. }\end{array}$ & $\begin{array}{l}\text { Kolejne wydłużenie horyzontu planistycznego w związku } \\
\text { z zobowiązaniem, które wygaśnie w roku 2045, oraz stosow- } \\
\text { na modyfikacja raportów dotyczących budżetu i raportów } \\
\text { dotyczących przedsięwzięć wieloletnich. }\end{array}$ \\
\hline
\end{tabular}

Źródło: opracowanie własne na podstawie dokumentów planistycznych m.st. Warszawy.

Badanie procesu planowania budżetowego m.st. Warszawy dla okresu 2008-2016 wskazuje na dokonanie przez zarządzających daleko idących zmian i modyfikacji, w wyniku których proces planistyczny i dokumenty planistyczne pierwotnie dotyczące budżetu rocznego w układzie klasyfikacji budżetowej (w 2007 r.) obejmują obecnie (2017 r.) budżet wieloletni w postaci WPF z horyzontem planistycznym do $2045 \mathrm{w}$ układzie klasyfikacji budżetowej oraz w układzie zadaniowym, powiązany $\mathrm{z}$ rocznym budżetem $\mathrm{w}$ układzie klasyfikacji budżetowej oraz w układzie zadaniowym wraz z rozwinięciem klasyfikacyjnym według tzw. budżetu obywatelskiego. Dokumenty planistyczne uzupełnia sformalizowana polityka długu m.st. Warszawy.

\section{Kluczowa rola planowania wieloletniego w JST}

Od 2011 r. JST wraz z projektem uchwały budżetowej przedkładają do 15 listopada roku poprzedzającego rok budżetowy projekt uchwały w sprawie wieloletniej prognozy finansowej [Ustawa z 27 sierpnia 2009]. Obejmuje ona okres roku budżetowego oraz co najmniej trzech kolejnych lat budżetowych. Elementem prognozy finansowej jest prognoza długu, którą sporządza się na okres, na który zaciągnięto oraz planuje się zaciągnąć zobowiązania. Wieloletnie zobowiązania to te, które mogą wynikać z udzielonych poręczeń lub gwarancji, zaciągniętych kredytów, wyemitowanych obligacji oraz z zawartych długoterminowych umów na realizację zadań JST. W uproszczeniu, to ostatni rok realizacji tych zobowiązań wyznacza okres 
objęty wieloletnią prognozą finansową. Ustawodawca określił obowiązkowy zakres przedmiotowy wieloletniej prognozy finansowej. Obejmuje ona dwa zestawienia: wieloletnią prognozę finansową oraz wykaz wieloletnich przedsięwzięć. Wzór wieloletniej prognozy finansowej określił w 2013 r. Minister Finansów [Rozporządzenie Ministra Finansów z 10 stycznia 2013]. Składa się on z 16 sekcji, takich jak: dochody, wydatki, wynik budżetu, przychody, rozchody, kwota długu, kwota zobowiązań wynikających z przejęcia zobowiązań po likwidowanych i przekształconych jednostkach zaliczanych do sektora finansów publicznych, relacja zrównoważenia wydatków bieżących, wskaźniki spłaty zobowiązań oraz informacje uzupełniające, np. dotyczące kwot na wynagrodzenia i pochodne od nich. Ponadto we wzorze WPF ujęto wydatki związane z funkcjonowaniem organów JST, wydatki objęte limitem wykazane w wykazie przedsięwzięć, wydatki inwestycyjne, finansowanie zadań z udziałem środków UE.

Wskazuje się, że wdrożenie WPF zachęca JST do koncentrowania zasobów finansowych na kluczowych przedsięwzięciach oraz pomaga $\mathrm{w}$ identyfikacji potencjalnych napięć budżetowych. W efekcie uznano WPF za narzędzie usprawniające lokalną politykę fiskalną $\mathrm{w}$ aspekcie wiarygodności, przejrzystości i przewidywalności [Adamiak 2012]. Opracowanie WPF umożliwia weryfikację długookresowej stabilności finansowej JST rozumianej jako zdolność do obsługi zobowiązań i utrzymania płynności finansowej [Krajewski, Mackiewicz, Krajewski 2010]. W badaniach dotyczących krajów o dłuższej już tradycji planowania wieloletniego w JST wskazuje się oprócz wielu korzyści związanych z planowaniem wieloletnim również na potencjalne mankamenty, jak np. usztywnienie polityki fiskalnej związane z nadmiernym przenoszeniem w prognozach obecnej sytuacji budżetowej i obecnych uwarunkowań fiskalnych czy też nadmiernie optymistyczne planowanie wydatków [Boex, Vazquez, McNab 1998]. W Polsce Minister Finansów udostępnia dane dotyczące WPF wszystkich JST [https3]. Na podstawie udostępnionego zbioru danych zbadano kształtowanie się okresu prognozowania WPF. Tylko 10\% JST prognozuje w okresie krótszym niż 6 lat. W perspektywie dziesięcioletniej i dłuższej prognozuje ponad połowa JST (57\%). Ponad setka JST sporządza WPF na okres dłuższy niż 20 lat, w tym 8 JST prognozuje w horyzoncie przekraczającym 30 lat.

\section{Zarys mechanizmu powiązania planowania strategicznego $\mathrm{z}$ wieloletnim planowaniem finansowym}

W literaturze przedmiotu podkreśla się, iż zwiększenie potencjału rozwojowego JST możliwe będzie między innymi poprzez powiązanie procesu planowania strategicznego z wieloletnim planowaniem finansowym i inwestycyjnym [Cichocki 2017]. Jako wzorzec wskazuje się, iż wieloletnia prognoza finansowa powinna być finansową egzemplifikacją planów strategicznych, a wieloletni wymiar planowania koncentruje dyskusje budżetowe na długoterminowych celach władzy [Franek 2011]. Powiązanie budżetu oraz WPF z zapisami dokumentów strategicznych pozwala na 
uruchomienie mechanizmu wzrostu efektywności oraz, co istotne, mechanizmu wzrostu transparentności, w wyniku którego zarządzający strategią, realizatorzy strategii, mieszkańcy i instytucje współpracujące i zainteresowane współpracą z JST otrzymają informację o planowanych środkach finansowych przeznaczanych na realizacje celów określonych w strategii JST. Przyczynia się to do poprawy efektywności planowania i monitorowania realizacji strategii JST.

W propozycji mechanizmu powiązania planowania strategicznego z planowaniem finansowym zakłada się, że zarówno budżet JST, jak i WPF opracowywane są w systemie informatycznym umożliwiającym przyporządkowanie do każdego zadania budżetowego: dysponenta, klasyfikacji budżetowej (dział, rozdział, paragraf), programu budżetowego (w układzie budżetu zadaniowego), obszaru funkcjonalnego (w sytuacji konieczności kontroli powiązania wydatku z dochodem, np. w zakresie projektów unijnych), a ponadto, w przypadku wydatków wieloletnich, zakłada się, że system umożliwia ewidencję tzw. przedsięwzięć stanowiących planistyczną podstawę do zaciągania zobowiązań wieloletnich. W efekcie, poprzez zastosowanie odpowiedniego systemu kodów, możliwe jest systemowe ewidencjonowanie wydatków oraz dalsze ich przetwarzanie dla potrzeb kontrolnych i analitycznych. Powyższe założenia stanowią punkt wyjścia do mechanizmu powiązania procesu planowania finansowego obejmującego planowanie roczne i wieloletnie z planowaniem strategicznym, w szczególności z aktualną strategią JST. W hierarchii dokumentów strategicznych dla potrzeb proponowanego mechanizmu wyodrębnia się: strategię, programy rozwoju, plany roczne. Strategia obejmuje: wizję, cele strategiczne, cele operacyjne. Programy rozwoju mają charakter interdyscyplinarny i obejmują: cel główny (odpowiadający celowi operacyjnemu ze strategii), cele szczegółowe, działania, projekty. Plany roczne mają charakter nieinterdyscyplinarny i obejmują projekty (odpowiadające projektowi z programów rozwoju) oraz zadania bieżące. $\mathrm{Z}$ uwagi na złożoność mechanizmu wiązania planowania strategicznego z planowaniem finansowym podzielony jest on na dwa etapy wdrożeniowe. W pierwszym etapie zakłada się wdrożenie powiązania wybranych elementów strategii, takich jak cele strategiczne i cele operacyjne, z rocznym budżetem oraz WPF. W pierwszym etapie powiązaniem ze strategią objęte są wszystkie zadania i wieloletnie przedsięwzięcia majątkowe oraz dodatkowo tylko zadania i wieloletnie przedsięwzięcia bieżące finansowane z funduszy europejskich. Dla każdego wydatku spełniającego ww. wymogi określa się na tym etapie kod klasyfikacyjny przedstawiony na rys. 1 .

\begin{tabular}{|l|l|l|l|l|l|l|l|l|l|l|}
\hline Nr pola & 1 & 2 & 3 & 4 & 5 & 6 & 7 & 8 & 9 & 10 \\
\hline $\begin{array}{l}\text { Kod } \\
\text { klas. }\end{array}$ & & & & & & & & & & \\
\hline
\end{tabular}

Rys. 1. Schemat kodu klasyfikacyjnego wiązania kierunków wydatkowania z celami określonymi w strategii

Źródło: opracowanie własne. 
Pole nr 1: służy do określenia, czy wydatek służy realizacji strategii (S), czy też nie dotyczy realizacji strategii $(\mathrm{N})$. Pole $\mathrm{nr}$ 2: służy do określenia, który z celów strategicznych będzie realizowany poprzez ten wydatek ( 1 - określa cel strategiczny $\mathrm{nr} 1,2$ - określa cel strategiczny $\mathrm{nr} 2$ itd.). Pole $\mathrm{nr} 3$ : służy do określenia numeru celu operacyjnego ( 1 - określa cel operacyjny nr 1,2 - określa cel operacyjny nr 2 itd.). Pola $\mathrm{nr} 4-10$ pozostają jako rezerwa systemowa. W drugim etapie prac wdrożeniowych nad powiązaniem strategii z budżetem i WPF dołącza się powiązania dotyczące wydatków i przedsięwzięć nieujętych w pierwszym etapie, to jest wydatki i przedsięwzięcia bieżące niefinansowane z funduszy europejskich. Na tym etapie pola nr 6-7: służą do określenia kierunku działania (1 - określa działanie nr 1, 2 - określa działanie $\mathrm{nr} 2$ itd.). Pola nr 8-10 pozostają jako rezerwa systemowa do wykorzystania przy ewentualnym poszerzeniu klasyfikacji.

Do zalet proponowanego systemu powiązania między strategią a planami finansowymi należy przede wszystkim możliwość precyzyjnej alokacji środków budżetowych zgodnie z przyjętą strategią JST. Mechanizm ten umożliwia również systemowe monitorowanie wydatków na realizację strategii. Nowa formuła stwarza JST możliwości ustalenia optymalnej hierarchii zadań planowanych w ramach strategii i może być podstawą do wprowadzenia zarządzania w oparciu o portfele projektów.

Natomiast do wad proponowanego mechanizmu można zaliczyć zwiększenie pracochłonności związane z koniecznością dodatkowego sklasyfikowania wydatku, zarówno na etapie konstruowania projektu budżetu i WPF, jak i na etapie zmian w trakcie roku budżetowego. Należy liczyć się też z koniecznością wydłużenia procesu planowania i realizacji wydatków budżetowych $\mathrm{z}$ uwagi na włączenie do procesu weryfikacyjnego wydatków pracowników odpowiadających za wdrożenie i kontrolę realizację strategii.

\section{Zakończenie}

JST wydłużyły horyzont planistyczny z okresu rocznego na okres kilku, kilkunastu bądź kilkudziesięciu lat. Wprowadzenie obowiązku planowania wieloletniego zobowiązuje JST do planowania co najmniej na okres 4 lat, jednak, jak wykazują badania, ponad połowa JST planuje w horyzoncie przekraczającym 10 lat. Planowanie budżetowe ewoluuje nie tylko co do horyzontu planistycznego, ale też co do formy prezentacji danych, to jest od danych w układzie klasyfikacji budżetowej dla rocznego budżetu do planów wieloletnich w układzie klasyfikacji budżetowej oraz $\mathrm{w}$ układzie zadaniowym $\mathrm{z}$ horyzontem planistycznym przekraczającym okres 20 lat. Pozytywne zmiany w zakresie zarządzania finansami JST odzwierciedla ewolucja procesu planowania budżetowego dokonana w ciągu ostatniej dekady w samorządzie Warszawy. W modelowych rozwiązaniach zarządzanie finansami JST powinno być zintegrowane z takimi instrumentami zarządzania strategicznego, jak strategie rozwoju gminy, powiatu czy województwa [Sierak 2013]. Dopełnieniem procesu podnoszenia sprawności i efektywności w planowaniu i wydatkowaniu 
Środków publicznych może stać się zaproponowany mechanizm powiązania kierunków wydatkowania określonych w WPF i rocznym budżecie z celami i zadaniami określonymi w strategii JST.

\section{Literatura}

Adamiak J., 2012, Wieloletnia prognoza finansowa jako narzędzie zarządzania finansami lokalnymi, Finanse Komunalne, nr 1-2.

Boex J., Vazquez M.J., McNab R., 1998, Multi Year Budgeting: A Review of International Practices and Lessons for Developing and Transitional Economies, Andrew Young School of Policy Studies Georgia State University, International Studies Program, Working Papier, no. 98-4.

Cichocki K.S., 2017, Finansowanie rozwoju samorzadu terytorialnego - doświadczenia międzynarodowe, Finanse Komunalne, nr 12.

Dylewski M., 2014, Performance budgeting - ewolucja i determinanty zastosowania w jednostkach samorządu terytorialnego, Zeszyty Naukowe Uniwersytetu Szczecińskiego, nr 802, Finanse, Rynki Finansowe, Ubezpieczenia, nr 65.

Franek S., 2011, Wieloletnie planowanie budżetowe w praktyce międzynarodowej i polskiej, [w:] Kierunki modernizacji zarzadzania w jednostkach samorzadu terytorialnego, red. T. Lubińska, Difin, Warszawa, s. 72-73.

Krajewska M., Jońca A., 2012, Wieloletnia prognoza finansowa jako instrument zarzadzania gospodarka finansowa jednostek samorządu terytorialnego - podsumowanie dwóch lat doświadczen, Finanse Komunalne, nr 11, s. 28-29.

Krajewski S., Mackiewicz M., Krajewski P., 2010, Przygotowanie wieloletniej prognozy finansowejwybrane problemy metodologiczne, Finanse Komunalne, nr 7-8.

Miemiec W., 2015, Budżet zadaniowy jako metoda planowania budżetowego, Acta Universitatis Wratislaviensis, nr 3661, Przegląd Prawa i Administracji C/2.

Rozporządzenie Ministra Finansów z dnia 10 stycznia 2013 r. w sprawie wieloletniej prognozy finansowej jednostki samorządu terytorialnego, Dz.U. 2015, poz. 92 j.t.

Sierak J., 2013, Zarządzanie strategiczne w jednostkach samorządu terytorialnego, Myśl Ekonomiczna i Polityczna, $\mathrm{nr} 4$.

Ustawa z 27 sierpnia 2009 r. o finansach publicznych, Dz.U. 2017, poz. 2077 j.t.

[https1] www.bip.warszawa.pl/dokumenty/budzet_finanse/wpf/WPF_2018-2045 (22.01.2018).

[https2] www.bip.warszawa.pl/dokumenty/budzet_finanse/kompendium (22.01.2018).

[http3]www.mf.gov.pl/ministerstwo-finansow/dzialalnosc/finanse-publiczne/budzety-jednostek-samorzadu-terytorialnego/sprawozdania-budzetowe (24.01.2018). 